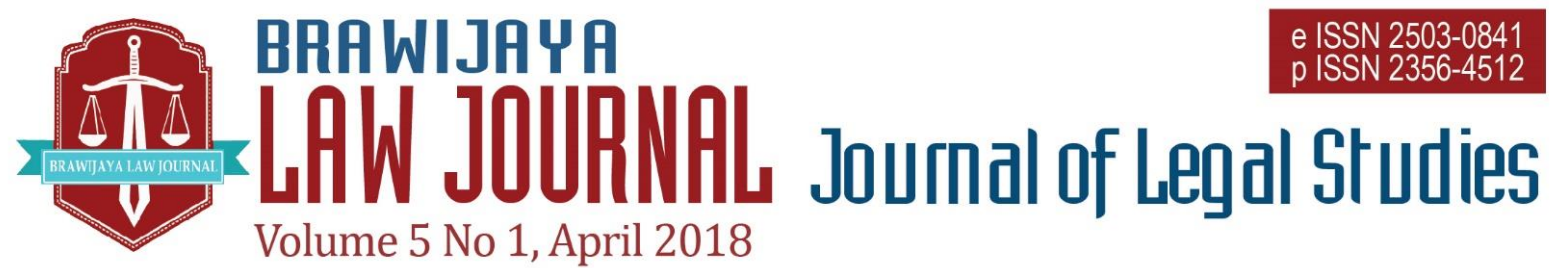

Nationally Accredited No. 32a/E/KPT/2017 Dated 26th April 2017

This work is licensed under a Creative Commons Attribution-NonCommercial 4.0 International License

\title{
In Search of Remotely Piloted Aircraft Regulations State Practices and International Law Perspective What Indonesia can Learn?
}

\author{
Atip Latipulhayat Uweh ${ }^{1}$, Neni Ruhaeni ${ }^{2}$ \\ ${ }^{1}$ Faculty of Law - Padjadjaran University \\ E-mail : atip.latipulhayat@unpad.ac.id \\ ${ }^{2}$ Bandung Islamic University \\ E-mail: nenihayat@gmail.com
}

Submitted : 2017-10-18 | Accepted : 2018-04-11

\begin{abstract}
Remotely Piloted Aircraft (RPA) has been used for different purposes, from hobby to military purposes. The rapid development of RPA's technology has made RPA regulations in most countries become more quickly obsolete. It is exacerbated by the fact that there is no agreed internationally RPA regulation so far, except an amendment of Annex 2 of the Chicago Convention 1944, which broadens the notion of aircraft to include RPA.

This article identifies legal issues and models of RPA regulation in several countries and what Indonesia can learn and to look for an adequate and appropriate model to make the Indonesian RPA regulation, legally acceptable and technologically adaptable. This paper argues that the Chicago Convention, the model of RPA regulations in several countries, and the special interests of Indonesia as an archipelagic state are the three important elements that should be taken into account in the establishment of an appropriate and adequate Indonesian $R P A$ regulation. This paper used normative method whcih analysing existing legal framework in $R P A$
\end{abstract}

Keywords: $\quad R P A$, regulations, Chicago Convention, Indonesia, aircraft.

\section{INTRODUCTION}

Drone or Remotely Piloted Aircraft (hereafter referred to RPA) represents a new development in aviation technology used for a variety of purposes, from hobby to military purposes. Unlike aircrafts used for civil aviation purposes, which is governed by comprehensive rules, RPA operations is still based on a number of ad hoc rules in both international as well as domestic levels. It is exacerbated by the fact that there is no agreed internationally RPA regulation so far, except an amendment of Annex 2 of the Chicago Convention 1944 (hereafter referred to as the Convention), which broadens the notion of aircraft to include RPA. One of the important consequences of that is the creation of decentralized RPA regulation models, which give more space for states to establish their national RPA regulations. 
The rapid development of RPA's technology and its multi-purpose uses has made RPA regulations in most countries become more quickly obsolete. In addition, RPA operations produce not only legal, but also social, and ethical implications. Social implications generally involve opportunities and threats of using RPA for society. While ethical issues pertain to the use of certain types of RPA that potentially violate moral values or the use of RPA that requires application of certain moral values as well. The legal issues are mostly related to the urgent need to make legal frameworks about what actions (operations) are allowed and what should be allowed. ${ }^{1}$

This article identifies legal issues and models of RPA regulation in several countries and what Indonesia can learn and to look for an adequate and appropriate model to make the existing Indonesian RPA regulation, legally acceptable and technologically adaptable. The article begins with the explanation of the term RPA and its status and legal position under the Convention. The next discussion is to identify the model of RPA regulations in several countries including the existing Indonesian RPA regulations. Finally, this article will propose an appropriate RPA regulation model for Indonesia.

\section{LEGAL MATERIALS AND METHODS}

While the primary legal materials consist of all the international agreement related to the development of technology both directly and indirectly, secondary ones included the references, including books, journal articles as well as conference papers and other documents having correlation with the issues. The technique of analysis data used legal interpretation. Specifically, the international agreements as primary legal materials include: Act No. 74 of 1962 (as amended up to 1991), Namibian Civil Aviation Regulations, 2001, Amendment No. 6 to the International Standards and Recommended Practices, Aircraft Nationality and Registration Marks (Annex 7 to the Convention on International Civil Aviation), adopted by the Council of ICAO on 7 March 2012, Amandement No. 43 to International Standards Rules of the Air, Annex 2 The Convention on International Civil Aviation Organization, 7 March 2012, Amendment No. 43 of Annex 2 of 2012, Law No.15 of 2002 of the State of Qatar, Permenhub No.PM 47/2016, Permenhub No. PM 90/2015, Permenhub No.PM 90/2015, Permenhub No.PM 180/2015, South African Civil Aviation Authority, Technical Guidance Material for RPAS_Part 101, § 6, 30 Sept 2015 and The Chicago Convention 1944.

\section{RESULTS AND DISCUSSIONS Remotely Piloted Aircraft}

Drone is a popular name for Unmanned Aircraft (UA) or Remotely Piloted Aircraft (RPA), which was often officially used by governments in pre-Gulf War times (19901991). ${ }^{2}$ In the official vocabulary of the US Army, drone is defined as a land, sea or air vehicle that is remotely or automatically

\footnotetext{
${ }^{2}$ Mark Edward Peterson, 'The UAV and the current and future regulatory construct for integration into the national airspace system', (2010) 713 Journal of Air Law and Commerce, 528.
}

\footnotetext{
${ }^{1}$ Burt Custer, "Drones Here, There and Everywhere: Introduction and Overview" in Burt Custers (Ed.), The Future of Drone Use: Opportunities and Threats From Ethical and Legal Perspectives, Springer, 8
} 
controlled. ${ }^{3}$ This definition shows that drone does not only include UA, but also aerial vehicle that can be controlled either from a distance by human operators (remote control) or automatically controlled. There may be as many different kinds as there are families of weapons: terrestrial drones, marine drones, submarine drones, even 'subterranean drones' imagined in the form of fat mechanical moles. Provided there is no longer any human crew aboard, any kind of vehicle or piloted engine can be "dronized". 4

Drone can be controlled either remotely by human operators (remote control) or autonomously by robotic means (automatic piloting). In practice, modern drones mostly combine those two modes of control. In addition to the three families of drone, the popular term generally refers to aerial vehicle known as Unmanned Aerial Vehicles (UAVs) or Unmanned Combat Aerial Vehicles (UCAVs), depending on whether the contraption carries weapons. ${ }^{5}$ This can be seen for example in the definition of UAV from the US Department of Defense as follows: ${ }^{6}$

.... a powered, aerial vehicle that does not carry a human operator, uses aerodynamic forces to provide vehicle lift, can fly autonomously or be piloted remotely, can be expendable or recoverable, and can carry a lethal or non-lethal payload.

Since UAVs may carry lethal weapons such as missiles or bombs, these can be used for military purposes.

\footnotetext{
${ }^{3}$ Gregoire Chamayou, A Theory of The Drone, (The New Press, New York, London, 2015) 11.

${ }^{4}$ Ibid.

${ }^{5}$ Ibid.

6 Joint Publication 1-20, Department of Defense Dictionary of Military and Associated Terms, March 23, 1994, as amended through April 15, 1998, pp. 138,369 , and 459 .
}

However, since drone is becoming politically unpopular, governmental and nongovernmental entities now often avoid using this term. ${ }^{7}$ The term 'drone' is not recognised or used, for instance, by the Federal Aviation Administration (FAA). With the move away from the term 'drone', Unmanned Aerial Vehicle (UAV) or Unmanned Aircraft Systems (UAS) are often popularly used, especially among the media. There are various names referring to UAV in Indonesian language, such as Pesawat Udara Nir Awak (Unmmanned Aircraft), Drone, or Pesawat Udara Tanpa Awak (Unmanned Aircraft). In the English literatures there are various terms that also refer to unmanned aircraft such as, Unmanned Aircraft Systems (UAS), Unmanned Aerial Vehicles (UAV), Remotely Piloted Aircraft System (RPAS), and Drone.

Unmanned Aircraft System (UAS) can be defined as aerodynamic flying systems that can be piloted remotely via a joystick or digital interface supported by different levels of automatic control. ${ }^{8}$ UAS is automatically controlled through a designed computer program, or remote control of pilots or operators on the ground or elsewhere instead aboard. In short, it can be concluded that UAS is an aircraft, which is not operated by pilot aboard.

ICAO (International Civil Aviation Organization) uses the term RPA as an aircraft that is controlled from remote pilot station. ${ }^{9}$ According to ICAO, RPA shall be operated in such a manner as to minimize hazards to persons, property or other aircraft

\footnotetext{
${ }^{7}$ Peterson, above n. 2

8 Ales Zavrsnik, "Situating Drones in Surveillance Societies" in Ales Zavrsnik (Ed), Drones and Unmanned Aerial Systems: Legal and Social Implications for Security and Surveillance, (Springer, London) 1.

${ }^{9}$ Amendment No. 6 to the International Standards and Recommended Practices, Aircraft Nationality and
} 
and in accordance with the specific conditions. $^{10}$ For that reason, ICAO emphasizes RPA regulations to licenses, frequency usage, supervision and communication in the operation of RPA. Indonesia has issued the Regulation of the Ministry of Transportation of the Republic of Indonesia No. 90 of 2015 on Unmanned Aircraft (UA) Operated in the Indonesian air space, which defines UA as aircraft that operates with remote control by pilots or is able to control itself using aerodynamic rules. $^{11}$

Although there has no agreed definition of unmanned aircraft so far, it has a common or specific characteristic, the absence of pilot aboard to control the aircraft. This characteristic depicts the nature of an unmanned aircraft and confirming the term RPA as used by ICAO. For that reason, this paper uses the term RPA to refers to all kind and forms of unmanned aircraft.

\section{Legal Status of RPA}

Is RPA an aircraft under the Convention? This is an important question as this Convention does apply only to civil aircraft. ${ }^{12}$ The Convention defines aircraft as follows:

Any machines that can derive support in the atmosphere, from the reactions of the air other than the reactions of the air against the earth's surface. ${ }^{13}$

This definition reveals that the winged or helicopter vehicle, which is capable of

Registration Marks (Annex 7 to the Convention on International Civil Aviation), adopted by the Council of ICAO on 7 March 2012, p. 3.

${ }^{10}$ Chapter 3 Amandement No. 43 to International Standards Rules of the Air, Annex 2 The Convention on International Civil Aviation Organization, 7 March 2012.

${ }^{11}$ Article 1.2.2 Permenhub No. PM 90/2015. achieving lift constitutes an aircraft. Since most RPAs use winged and helicopter technologies, they can be categorized aircraft as prescribed under the Convention. ICAO subsequently broadened this definition by amending Annex 2 of the Convention and inserting the term RPA into the definition of aircraft. ${ }^{14}$ Thus, ICAO explicitly recognizes RPA as an aircraft and confirms that the term aircraft includes aerial vehicle, which is controlled from remote pilot station.

The recognition RPA as an aircraft is not only a response to technological development of unmanned aircraft, but also justifies the use of the phrase 'aircraft without pilot' under the Convention in modern aviation. The Convention states as follows: ${ }^{15}$

No aircraft capable of being flown without a pilot shall be flown without a pilot over the territory of a contracting State without special authorization by that State and in accordance with the terms of such authorization. Each contracting State undertakes to insure that the flight of such aircraft without a pilot in regions open to civil aircraft shall be so controlled as to obviate danger to civil aircraft.

Historically, the phrase "aircraft without a pilot" referred to an unmanned balloon during World War II that used to carry bombs and spying activities into the enemy's territory. ${ }^{16}$ This was intended as an aircraft for military purposes. The amendment to

12 Article 3 of the Chicago Convention states as follows: "This Convention shall be applicable only to civil aircraft, and shall not be applicable to state aircraft".

${ }^{13}$ Annexes 2, 6 \& 8 of the Chicago Convention.

${ }^{14}$ Amendment No. 43 of Annex 2 of 2012.

${ }^{15}$ Article 8 of the Chicago Convention.

16 D.M. Marshal, 'International Regulation of Unmanned Aircraft Operations in Offshore and 
Annex 2 of the Convention by inserting the term RPA into the definition of aircraft seemed to be a contextualisation the phrase "aircraft without pilot" in Article 8 of the Convention, which is no longer limited to military, but also non-military purposes.

Presently, however, the use of RPA especially by developed countries such as the United States appears to confirm the basic idea of Article 8 of the Convention, which is more focused on using RPA for military purposes. It is therefore not surprising if the US Department of Defense defines RPA as follows: ${ }^{17}$

a powered aerial vehicle that uses aerodynamic forces to provide vehicle lifts, can fly autonomously or be piloted remotely, can be expendable or recoverable, and carry a lethal or nonlethal payload.

\section{RPA and Chicago Convention of 1944}

The Convention stipulates that every state has complete and exclusive sovereignty over the air space above its territory, which gives the states the right to exercise its sovereignty in absolute terms. ${ }^{18}$ The Convention provides further that no aircraft including state aircraft of a contracting state fly over the territory of another state without authorization by that state and in accordance with the terms of such authorization. ${ }^{19}$ Since RPA meets the criteria of an aircraft as prescribed under the Convention, there are two important questions needs for further discuss. First, does the principle of state sovereignty in air space apply to RPA?

International Airspace',(2012) 878 Issues in Aviation Law and Policy, 93.

${ }^{17}$ Ruwantissa Abeyratne, Convention on International Civil Aviation: A Commentary, (Springer, London, 2014), 121.

${ }^{18}$ E.M.Giemulla and L.Weber, International and EU Aviation Law: Selected Issues, (Kluwer Law International, Dordrecht, 2011), 6.
Secondly, does the Convention apply also to state aircraft?

There are two different ways to answer the questions, restrictive and inclusive approaches. The restrictive approach holds that the principle of sovereignty applies only to civil aircraft. Their argument mainly based on the text of Article I of the Convention, which states as follows:

The contracting States recognize that every State has complete and exclusive sovereignty over the air space above its territory.

The article should be read in parallel with the provision of Article 3 (a) of the Convention, which states explicitly that the Convention is applicable only to civil aircraft, and shall not be applicable to state aircraft. More importantly, the spirit of the Convention as it is stated in its preamble is to govern the civil aviation and for that reason this Convention applies only to civil aircraft. The preamble of the Convention states as follows:

.....the future development of international civil aviation can greatly help to create and preserve friendship and understanding among the nations and peoples of the world, yet its abuse can become a threat to the general security (emphasize added).

They also specifically refer to Article 3 (c) of the Convention, which does not allow state aircrafts to fly over the territory of another state or land thereon without authorization by special agreement or otherwise, and in accordance with the terms thereof. ${ }^{20}$ This

${ }^{19}$ Article 1, 3 (c), 8 of the Chicago Convention.

${ }^{20}$ Article 3 (c) of the Chicago Convention: No state aircraft of a contracting State shall fly over the territory of another State or land thereon without authorization by special agreement or other- wise, and in accordance with the terms thereof.

58 | Uweh, Ruhaeni - In Search of Remotely Piloted Aircraft Regulations State Practices... 
provision is originally adopted from the Paris Convention of 1919 that governs the same object. In other words, this provision reaffirms that the state aircraft is not civil aircraft, which is subject to the provisions of the Convention. In this regard Lissitzyn states as follows: ${ }^{21}$

Is the omission in the Chicago Convention of the rules on the privileges of foreign military and other state aircraft contained in Articles 32 and 33 of the Paris Convention intended to imply some change of law? Or is it merely due to a feeling that provisions dealing with jurisdiction over military aircraft are out of place in a civil aviation prevention? The publish records of the Chicago Convention give no clue to the answer, but the second explanation seems to be the likely one.

By referring to Article 8 of the Convention they argue that this is a lex specialis provision as this specifically governs the operation of RPA. Article 8 states as follows:

No aircraft capable of being flown without a pilot shall be flown without a pilot over the territory of a contracting State without special authorization by that State and in accordance with the terms of such authorization. Each contracting State undertakes to insure that the flight of such aircraft without a pilot in regions open to civil aircraft shall be so controlled as to obviate danger to civil aircraft.

This Article provides that RPA is not permitted to fly over the territory of another countries without special authorization of that state. More specifically, this provision is not applicable to RPA that falls under state aircraft category, as this Article should be read in line with the provisions of Article 3 (a) of the Convention, which clearly states that the provisions of the Convention including Article 8 applies only to civil aircraft as well as to RPA for civil aviation purposes. $^{22}$

Unlike the restrictive, the inclusive approach contends that the principle of state sovereignty in the Convention applies also to state aircraft. Interestingly, while they refer to the same provisions of the Convention as used by the first approach, they have different interpretations. They argue that the complete and exclusive sovereignty of state above its territory should be read in general meaning in the sense that this is not applicable only to civil, but also state aircraft. It gives the state the right to use its airspace for all types of aircraft. More importantly, Article 1 of the Convention, which establishes the principle of state sovereignty over the airspace and it constitutes the spirit of the Convention, does not use the term 'civil or state air craft'. This clearly shows that the principle of state sovereignty over the airspace should be interpreted in a broad sense; it is not exclusively for civil aircraft. In this regard, Giemulla and Webber neatly state as follows: ${ }^{23}$

This statement has to be understood in the context that article 1 of the

22 K.Dalamakidis, K.P.Valanis, and L.A.Piegl, 'Current Status and Future Perspectives for Unmanned Aircraft System Operations in the US', (2008) 52 Journal of Intelligent and Robotic System, 313.

${ }^{23}$ Giemulla and Webber, above n 18, 52 
Chicago Convention emphasizes the general international principle of sovereignty of the air as a principle that claims universal application and therefore also-but not exclusively - is a basic precondition for the Convention and its interpretation. Placing it in front of the description of the area of application of the Convention thus not only is an editorial question, but also serve to show that this principle shall apply to all possible cases. That is not only for civil aircraft and thereby for the application area of Convention, but also for State aircraft.

With regard to the term "state aircraft" as used in Article 3 (c) and 8, they hold that these are intended to ascertain that the principle of state sovereignty as set forth in Article 1 of the Convention applies to all types of aircraft, including RPA and state aircraft.

However, some have argued that the word "state aircraft", which is explicitly stated in Article 3 of the Convention appears to be regarded as a deceptive term. This may lead to a distorted conclusion that the Convention only applies to civil aircraft. Bourbonniere and Haeck argue that the crux of Article 3 is governing the international flight for civil and military purposes. ${ }^{24}$ This means that Article 3 (c) does not only govern the state aircraft that fly over the airspace of another state, but also the obligation of the state to observe the safety of its navigation. ${ }^{25}$ Thus, Article 3 (c) should be read as follows: “...no state aircraft of a contracting State

\footnotetext{
${ }^{24}$ M. Bourbonnierre and L. Haeck, "Military Aircraft and International Law: Chicago Opus3", (2001) 66 Journal of Air Law and Commerce, 894.
}

shall fly over the territory of another state...without its permission".

The last but not the least is that Article 8 is intended to reiterate the principle of state sovereignty in Article 1, which essentially confirms that this principle applies also to RPA. Some have argued that Article 8 applies also to RPA for military purposes or state RPA for two reasons. First, the words of Article 8 which is read as follows"... no aircraft capable of being flown without a pilot" indicates that this Article also recognizes all types of RPA, for civil or military purposes. The key word is on the word "no", which means all types of aircraft, either civil, state, or military aircraft. Secondly it is relating to the formulation of Article 8, especially the words "aircraft capable of being flown without a pilot" that historically was intended as a hot air balloon for the purpose of transporting bombs and other weapons (unmanned ballons) in War II. In other words, it is RPA for military purposes.

\section{RPA Model Regulations}

The absence of internationally agreed RPA regulations is the main reason for the establishment various national RPA regulations. The ammendment Annex 2 of the Convention, which incorporates RPA into the term aircraft, makes the convention provisions apply to RPA operations. However, it is not completely able to answer the legal issues arising from RPA operations, because there are specific issues which rules are not found in the Convention. This leads the states to set up their national RPA regulations with different approaches that reflect their specific interests in RPA

\footnotetext{
25 Ibid. See aslo Article 3 (d) of the Chicago Convention.
} 
operations. There are at least three approaches used by states in setting up their national RPA regulations, namely, consent and segmented approach, segmented approach, and risk-based approach. ${ }^{26}$

\section{Consent and Segmented Approach}

Consent and segmented aircraft-based approach governs RPAs operation by way of issuing government permission and stipulating RPA segmented by weight as the main provisions. The state sovereignty over the air space is the main legal basis for establishing government-based permission regulations. This approach, therefore, is also known as a restrictive approach. The RPAbased segmented by weight regulation is mostly based on safety and security considerations for RPA operations. Most countries in Africa and Asia apply the consent and segmented aircraft-based regulation models.

RPA has widely been used in many countries in Africa for various objectives that range from the United Nations peacekeeping missions to diamond mining to antipoaching, conservation, and wildlife protection efforts. However, there are few African countries that have RPA regulations, which among others, Kenya, Morocco, Nigeria, Namibia and South Africa. ${ }^{27}$ The content of the regulations are varies, for example, Morocco bans the import of RPA and remote-controlled flying objects. Kenya and Nigeria require government permision

\footnotetext{
${ }^{26}$ Timothy Ravich, “A Comparative Global Analysis of Drone Laws: Best Practices and Policies" in Burt Custers (Ed.), 304-317.

${ }^{27}$ Ibid. p. 305

${ }^{28}$ Ibid.

${ }^{29}$ See Act No. 74 of 1962 (as amended up to 1991), Namibian Civil Aviation Regulations, 2001, Part 101, Rules of the Air and General Operating Rules: Operation of Unmanned Free Balloons, Kites, Rockets and Remotely Piloted Aircraft, § 47.00.2. See also Ravich, p. 306
}

for RPA operations. Namibia and South Africa have relatively more comprehensive regulations that could become guidance for RPA operators. ${ }^{28}$ For example, the Namibian Civil Aviation Regulation, provides rules of air and general operating rules for remotely piloted aircraft, stating that, "no person shall, without the prior approval of the Director and under such conditions which the Director may determine, operate a kite or remotely piloted aircraft: (a) higher than $150 \mathrm{ft}$ above the surface; (b) within a published controlled zone, air traffic zone or air traffic area; and (c) closer than five nautical miles from the boundary of an aerodrome." In addition, the regulation imposes requirements for maintenance and aircraft registration with respect to remotely piloted aircraft. ${ }^{29}$

South Africa issued RPA regulation entitled "Eighth Amendment of the Civil Aviation Regulations, 2015". This regulation distinguishes RPA from toy aircraft and recreational aircraft, and classifying RPA by mass, impact velocity, height above ground, and flight rules. ${ }^{30}$ The rule governs about RPA maintenance, sale and resale, and aircraft registration. ${ }^{31}$ The rules also provide for commercial, corporate, non-profit, and private operations and disallow RPA owners from operating in weather conditions that obstruct the ability to view the drone; using a public road as a landing or takeoff point; operating in controlled airspace; or carrying dangerous goods as cargo on a RPA. ${ }^{32}$ The rules require drone pilots to be 18 years or

${ }^{30}$ South African Civil Aviation Authority, Technical Guidance Material for RPAS —Part 101, § 6, 30 Sept 2015.

31 Ibid.

${ }^{32}$ South Africa Civil Aviation Regulations Committee 2015. Proposed amendment of the civil aviation regulations, 2011, proposal for the insertion of part 101 of the civil aviation regulations. www.defenceweb.co.za/ pdf/SA CAA 101DECEMBER_2014_publication.pdf. Accessed 13 Februray 2018. 
older and to pass a theoretical knowledge examination and possess a valid remote pilot license. ${ }^{33}$

Most Asian countries have used RPA for different purposes and interests and apply consent and segmented aircraft approach to govern such operations. Japan has been using RPA since 1980s and in 2015 established "Robot Revolution Realization Committee" to review existing radio and civil aeronautics laws toward the end of establishing industryrun best practices for RPA. At the same time Japanese regulators drafted a bill that would ban RPA operations above residential areas and prohibit RPA flight "except during daytime." ${ }^{34}$ This would lead Japan in the same position with a number of other Asian jurisdictions that are restrictive of RPA operations.

Other Asian countries like Bhutan, Brunei, and India also apply a restrictive approach to RPA operations. They essentially outlaw civil RPA operations. Bhutan for example, do not allow for unauthorised RPA, irrespective of size or weight to fly in Bhutanese airspace. RPA operations in Brunei are illegal, punishable by a maximum fine of $\$ 50,000$ and a fiveyear prison sentence. Brunei has justified its RPA ban in terms of safety, as has the Republic of Azerbaijan, which requires RPA meet at least the same safety and operational standards as manned aircraft." 35 For the

33 South African Civil Aviation Authority, Technical Guidance Material for Part 101 Personal Licensing, Advisory Circular, 19 June 2015. http://www.caa.co.za/RPAS\%20

TGM/TGM\%20for\%20Personnel\%20Licensing\%2 0Part\%20101\%20(Sub-part\%203).pdf. Accessed 13 February 2018.

${ }^{34}$ Sharp A, Takahashi M, "Japan to bolster laws after drone lands on Abe's office roof, Bloomberg Business", $22 \quad$ Apr 2015. http://www.bloomberg.com/news/articles/201504-22/ drone-lands-on-roof-of-japanese-primeminister-s-office-in-tokyo as cited by Ravich, above n. 26, 307. reason of protecting against terrorist attact and safeguarding privacy rights, Cambodia also has prohibited civil RPA operations. Civil RPA operations in India are still not allowed until the civil aviation authority revises the existing policies. ${ }^{36}$

Other countries also require government approval for RPA operations. The Civil Aviation Authority of Sri Lanka for instance states that operation of RPA of weight $3 \mathrm{~kg}$ or more requires approval from the Civil Aviation Authority of Sri Lanka.”37 The Ministry of National Defense of Vietnam shall grant flight permission to Vietnamese and foreign military aircraft operating in flights in Vietnam and to unmanned aircraft." ${ }^{38}$ Malaysia has prohibited small aircraft weighing less than $20 \mathrm{~kg}$ from flying in "controlled airspace or within an aerodrome traffic zone, unless in either case the permission of the air traffic control unit has been obtained."39 Other countries requires governmen license such as China. RPA heavier than $7 \mathrm{~kg}$ must obtain a license from China's Civil Aviation Administration. ${ }^{40}$ For an aircraft that is heavier than $116 \mathrm{~kg}$ and operating in the integrated airspace, where manned aircraft also fly, the operator must have both a license and operating certificate. ${ }^{41}$

Although Hongkong and Philippines are regarded as the Asian countries that apply a more liberal approach of RPA regulations,

${ }^{35}$ Ravich, ibid.

${ }^{36}$ Ravich, ibid, p. 308.

${ }^{37}$ Ibid.

${ }^{38}$ Ibid.

39 Ibid.

$40 \quad$ http://www.cad.gov.hk/ english/model_aircraft.html. Accessed 13 February 2018

${ }^{41}$ Orzea E, “China's UAS regulation: an interesting precedent, November 2014, UAS VISION. http://www.suasnews.com/2014/11/32433/chinasuas-regulation-an-interesting- precedent/. Accessed 13 February 2018. 
their contents have similarities with other Asian countries. Hongkong provides that any person intending to operate RPA (regardless of size and weight), for nonrecreational purposes within Hong Kong must assent to certain operational limitations in advance of the intended date of operation, i.e., flight within $5 \mathrm{~km}$ of any aerodrome or over or within $50 \mathrm{~m}$ of any person, vessel, vehicle, or structure. ${ }^{42}$ Philippines have also come forward with detailed registration and operational requirements for RPA activities. Enforceable through fines and penalties, the Philippines regulations apply to both large and small and require owners and operators to register their equipment and secure a certification to operate. ${ }^{43}$

The RPA regulations of most Asian countries seem to be more restrictive model. However, it represents, borrowing the words of Ravich as an intermediate position where RPA operators can fly, but only after satisfying a burden of making a safety and qualification case to central authorities. ${ }^{44}$

\section{Risk-based approach}

The European Aviation Safety Agency (EASA) established RPAs regulations in 2017 and proposed three categories of operations in a single regulatory regime: Open, Specific, and Certified. More specifically, EASA introduced a risk-based approach to the regulation of unmanned aircraft through a "Concept of Operation." This has been developed to address two main goals: (1) to achieve the integration and acceptance of RPA into the existing aviation

42

http://www.cad.gov.hk/english/Unmanned_Aircra ft_Systems.html. Accessed 13 February 2018.

43 Ravich, above n. 26, 309.

${ }^{44}$ Ravich, above n. 26, 308.

${ }^{45}$ EASA, "European aviation safety agency, concept of operations for drones", 2015. http:// system in a safe and proportionate manner; and (2) to foster an innovative and competitive European drone industry creating new employment, particularly for small and mid-size enterprises. ${ }^{45}$ To this end, in August 2016 the EASA proposed the establishment of a Commission Regulation on Unmanned Aircraft Operations.

Despie the facts of the absence of unifying international standards of RPA regulations and the fragmentation of the regulations in Europe, it was the fastest developing area in the World for RPA operations by mid-2015, with 2495 operators of RPA weighing less than $150 \mathrm{~kg}$ and 114 RPAs manufacturers. ${ }^{46}$ Their regulations mostly emphasized on segment aircraft by weight, purpose (e.g. hobby or recreational) or commercial (revenue generating)), and performance (e.g., altitude restrictions, pilot qualification, registration, and/or licensing). France, for instance established general rules on the use of RPA (weighing from 2 to $150 \mathrm{~kg}$ ) for leisure, competition, specific activities, aerial work, etc. In addition, the rules classified RPA into seven operational categories based on mass. In this scheme, visual line of site operations are allowed for drones less than 25 $\mathrm{kg}$ in mass below $150 \mathrm{~m}$ over unpopulated areas and for less than $4 \mathrm{~kg}$ of mass over populated areas. All opera- tions are forbidden in the vicinity of airports, and subject to prior authorization over populated areas. Illegal RPAs operations carry a maximum sentence of a year in prison, as well as a $\$ 90,000$ fine. $^{47}$

www.easa.europa.eu/system/files/dfu/204696_EA SA_concept_drone_brochure_web.pdf. Accessed 13 February 2018

${ }^{46}$ Ravich, above n. 26, 309.

${ }^{47}$ Ibid, 309-310. 


\section{Discretion of Authority}

RPA regulations in the Middle East at the first instance more focused on governing RPA for military purposes. Recently, however, an emerging regulatory structure has emerged to govern civil RPA operations in several countries such as Bahrain, Egypt, Israel, Lebanon, Qatar, Turkey, and the United Arab Emirates (“UAE”). They mostly govern RPA operations based upon the discretion of authorities. Bahrain and Egypt, for example provide that unmanned aircraft may operate in the territory of the States only upon authorization by the Civil Aviations Authority. ${ }^{48}$

For the same reason, Qatar's Civil Aviation Law states that unmanned aircraft shall not fly in the territory without authorization from the Civil Aviation Authority. ${ }^{49}$ Unlike other countries such as Israel, Turkey, UAE, and Lebanon, those countries do not provide explicit direction how operators obtain such permission.

Other countries such as Israel, Turkey, UAE, and Lebanon have a bit different approaches as they use categorization of unmanned aircraft by weight for having permission. Israel use the U.S. and European models that apply airworthiness standards for creating a regular permitting process for nonmilitary unmanned flight. ${ }^{50}$ Turkey applies procedures for permitting the flight of unmanned aircraft with a maximum takeoff weight between 4 and $150 \mathrm{~kg} .{ }^{51}$ The UAE use regulatory guidance and licensing rules based

\footnotetext{
${ }^{48}$ Ibid. p. 311.

${ }^{49}$ Fahmy, H eba, "New rules in the works to regulate drone usage in Qatar, Doha News, 26 Mar 2015. http://dohanews.co/new-rules-in-the-works-toregulate-drone-usage-in-qatar/. Accessed 13 February 2018. See Article 30 of the Law No.15 of 2002 of the State of Qatar.

${ }^{50}$ Ravich, above n. 26, 312.

51 See http://web.shgm.gov.tr/en/s/2222-proceduresfor-certifi- cate-of-special-flight-permit. Accessed 13 February 2018.
}

on a categorization of unmanned aircraft by weight, e.g., low-capacity drones (not exceeding $25 \mathrm{~kg}$ in weight), mid-capacity drones (ranging from 25 to $150 \mathrm{~kg}$ ), and advanced capacity drones, exceeding 150 kg. ${ }^{52}$ The last but not the least, Lebanon provides that "no person shall operate a nonpiloted aircraft in flight except in accordance with a special flight operations certificate or an air operator certificate. ${ }^{, 53}$

\section{Segmented Approach}

Several countries in North America, Latin America, Canada, and Australia apply this approach to govern their RPA operations. The North American countries have been considered to represent the more robust RPAs policies and rules world-wide, however the content and orientation of RPAs regulations of most countries in that region apply the segmenting aircraft approach, especially segmenting by mass. For the same reason, since April 2015 Mexico implemented new rules with different weight classes with several classes of RPA permitted to fly only in daylight. ${ }^{54}$

Canada that follows European model provides that RPA less than $2 \mathrm{~kg}$ can be flown for any purposes without permission. For RPA that weight between 2.1 and $25 \mathrm{~kg}$ can be flown if Transport Canada is informed of the type and location of flight. RPA being used for work or research that weight more than $25 \mathrm{~kg}$ or recreational drones weighing over $35 \mathrm{~kg}$ can only be flown with a Special

52 United Arab Emirates, General Civil Aviation Authority, Operation of Unmanned Aerial Systems within the United Arab Emirates, CAR Part VII, Subpart 10, https://www.gcaa.gov.ae/ en/Pages/uas.aspx. Accessed 13 February 2018.

53 Lebanese Aviation Regulation, General Operating and Flight Rules (2002), Republic of Lebanon, Ministry of Public Works and Transport, Directorate General of Civil Aviation.

${ }^{54}$ Ravich, above n. 26, 312.

64 | Uweh, Ruhaeni - In Search of Remotely Piloted Aircraft Regulations State Practices... 
Flight Operations Certificate. All flights must stay below $90 \mathrm{~m}$, within line of site, far from airports, populated areas, and moving vehicles. "Work or research" RPA operators must have \$100,000 liability insurance, and all drones must give right- of-way to manned aircraft. ${ }^{55}$

In 2016 the U.S established the rules provided that RPA must be less than $55 \mathrm{lbs}$, operated within visual line of sight at a maximum speed of 87 knots and a maximum altitude $400 \mathrm{ft}$ above ground level. In addition, the U.S generally allows hobby and recreational RPA operators to fly within particular safety guidelines. However, commercial RPA is banned from operation unless it is exempted under specific requirements. ${ }^{56}$ One of the critics to the U.S policy of RPA is that relating to the delay in finalizing regulations for the integration of drones into the national airspace system. This lead to illegal operation of RPA in the territory of foreign countries as for instance it is explained by the permissible nature of both private and commercial drone operations nearby Canada. ${ }^{57}$

RPA has widely been used in Latin and South American countries for a variety of purposes ranging from wildlife and rainforest conservation to anti-drug trafficking. However, most of the countries have not established adequate RPA regulations governing such activities. Only a few countries, such as Argentina, Brazil, and Chile are featuring some of the most interesting RPA regulations.

In 2015 the Argentine Civil Aviation Authority has proposed a project to regulate RPA together with provisional regulations

\footnotetext{
55 Ibid, 313.

56 Federal Aviation Administration, Section 333 Frequently Asked Questions, https://www.faa.
}

for UAV. The regulations would not permit commercial operations, but would allow the operation of RPA weighing more than $10 \mathrm{~kg}$, provided operators are of legal age and have a special license, among other operational restrictions. Brazil more focuses on controlling its airspace rather than formally regulating commercial RPA usage. However, Brazil has proposed final set of rules for RPA weighing less than $25 \mathrm{~kg}$ to operate up to 400 ft. In addition, Brazil has has specifically proposed classifying UAV into three categories: Class III: from 0 to $25 \mathrm{~kg}$, Class II: from 26 to $150 \mathrm{~kg}$, and Class I: over 151 kg. In 2015, Chile presented the first regulations for civil use in Latin and South America, which do not authorize commercial operations, but rather establish where civil (non-military) RPA can fly subject to fines for violations of the rules of up to 22 million pesos \$US 35,000). ${ }^{58}$

Australia was the pioneer in the region to produce RPA rules, which was established since 2002. The rules required RPA operators to hold a valid Operator Certificate before operating for commercial purposes especially for all operations not conducted in a "clear designated airspace, aerodromes and populous areas and remains below $400 \mathrm{ft}$ AGL." However, civilian RPAs do not need to have such approval, but operators must stay at least $30 \mathrm{~m}$ away from others, keep their RPAs under $400 \mathrm{ft}$ and within line of sight, and RPAs must not be operated above a large gathering of people or within $5 \mathrm{~km}$ of an airport. New Zealand followed the Australian model to govern RPA operation. RPA must be flown under $400 \mathrm{ft}$, must be kept in the line of sight, can only fly during

\footnotetext{
gov/uas/legislative_programs/section_333/333_fa qs/\#q3. Accessed, 13 February 2018.

${ }^{57}$ Ravich, above n. 26

${ }^{58}$ Ravich, above n. 26, p.315-317.
} 
the day, must stay at least $4 \mathrm{~km}$ away from aerodromes, and must weigh under $25 \mathrm{~kg}$. New Zealand permits the commercial usage of RPA as long as other rules are followed. ${ }^{59}$

\section{Indonesian RPA Regulation Model}

Like other states, Indonesia set up RPA regulation as a response to various RPA operations, which have not specifically been governed by the Convention. Indonesia issued the first RPA regulation in 2015, which was then amended twice and the last amendment was in 2016. Indonesia uses the consent and segmented approach for its RPA regulation, which focuses on government permits and segmented RPA by mass for RPA operations.

\section{Consent and Segmented Approach}

Indonesia issued the Regulation of the Ministry of Transportation No.PM 90 /2015 on the Control of Operation of Unmanned Aircraft in Airspace Serviced by Indonesia as the first regulation on RPA. The main reason for the issuance of this regulation is that to ensure the safe operation of the RPA in the Indonesian airspace. This regulation consists of five chapters: introduction, general provisions on RPA operations, special provisions on RPA operations, restrictions on the use of RPA that carry certain tools, and legal sanctions.

The introductory section provides two things. First, it is the implementation of the rules, which is actually stating the purpose and the scope of this regulation. Secondly, it provides a number of definitions relating to RPA operations. The primary objective of this regulation is to ensure safety and security against possible dangers resulted from RPA operations. The scope of this regulation covers among others the requirements, limitations and permits for the operation of the RPA system in the Indonesian airspace. ${ }^{60}$

This regulation provides eight legal and technical definitions, which among others, the definition of RPA, prohibited area, restricted area, and controlled airspace. RPA is defined as a flying machine that works with remote control by pilots or is able to control itself by using aerodynamics laws. ${ }^{61}$ Prohibited areas are defined as certain airspace above land and / or waters, with the permanent and detailed restrictions for all aircrafts. ${ }^{62}$ Restricted areas are certain airspace above land and / or waters with nonpermanent restriction and can only be used for state flight operations and when not in use (inactive), this area can be used for civil aviation. ${ }^{63}$ Controlled airspace is a type of air space equiped with air traffic services such as air traffic control services, flight information services and alerting services. Other definitions are about Flight plan, Airport Flight Safety Area, uncontrolled airspace, and operators. ${ }^{64}$

The general provisions on RPA operations require three conditions. First, RPA can be operated by individuals, communities, and government agencies. Secondly, RPA should not be used in prohibited areas, restricted areas, and airport safety zones. Thirdly, RPA should not be operated in controlled airspace and uncontrolled airspace at the altitudes of more than $500 \mathrm{ft} .{ }^{65}$ Special provisions are granted to RPA operations for certain purposes such as country border patrols, maritime patrols,

\footnotetext{
${ }^{63}$ Ibid. Art.1.2.4

${ }^{64}$ Ibid. Art.1.2.6

${ }^{65}$ Ibid. Art. 2.2.1 - 2.2.3.
}

\footnotetext{
${ }^{59}$ Ravich, above n. 26, 317.

${ }^{60}$ Permenhub No.PM 90/2015, Art. 1.1

${ }^{61}$ Ibid. Art.1.2.2

${ }^{62}$ Ibid. Art.1.2.3
}

66 | Uweh, Ruhaeni - In Search of Remotely Piloted Aircraft Regulations State Practices... 
weather observations, surveys and mapping. In addition, RPA can be operated at an altitude of more than $500 \mathrm{ft}$ with the permission granted by the Directorate General of Civil Aviation (DGCV) ${ }^{66}$

The application for obtaining such a permission must be submitted to DGCV no later than 14 days prior to RPA operations by providing documents, which contains information such as: name and contact of operators, technical specification of airborne systems, ground system technical specifications, purpose of the flight, flight plan, insurance document, and pilot competency. ${ }^{67}$ The applicant must also provides information concerning the flight plan which includes, among other things, the identification of the RPA, the equipment carried (eg camera, sprayer, crank), estimated operation time, cruising speed, and flight route. After having permission from the DGCA, the operator should coordinate with the air navigation service unit responsible for the air space where RPA will operate. $^{68}$

This regulation also imposes a number of restrictions on RPA that carries certain equipment. RPA that carries camera is prohibited to operate $500 \mathrm{~m}$ from the outer limit of the prohibited areas or restricted areas. In the case RPA is used for photography, filming and mapping, it must provides a letter of permission from the authorized institution and the local government whose territory will be photographed, filmed or mapped. For RPAs carrying agricultural equipment only allowed to operate on the agricultural / plantation areas as described in the submitted flight plan. The operation of RPA in agricultural / plantation area is allowed if there is no settlement within $500 \mathrm{~m}$ from the outer limit of this area. RPAs that are used by the government for purposes such as border patrols, marine patrols, weather observations, scheduled and unscheduled surveys and mapping using individual flight plans is allowed to operate. ${ }^{69}$

The last but not the least, this regulation stipulates that operators who violate the rules and/ or is proven to be negligent shall be imposed sanctions according to the prescribed laws and regulations. This regulations, however, does not specifically mention the types of such legal sanctions, but it refers to other relevant rules, such as aviation laws. ${ }^{70}$

The government amended this regulation by issuing Ministerial Regulation No.PM 180/2015. Although it is not specifically stated, the absence and unclarity of several technical and legal terms in the previous regulation, which are necessary for RPA operations, are the reasons for this amendment. Unlike the previous one, the new regulation explicitly determines the limits of air space for RPA operations. However, this new regulation does not define the flight plan, while this term is still used as one of the special requirements to obtain RPAs operating permissions. If the reason is that because it has already been regulated in the previous regulation, why the same definition appears in the new regulations, so it makes rather superfluous and overlapping rules.

This new regulation provides an additional explanation of the terms prohibited and restricted areas that are the area, which are published in the Indonesian

${ }^{69}$ Ibid. Art. 4.4.1-4.4.5

${ }^{70}$ Ibid. Art.5
${ }^{66} \mathrm{Ibid}$. Art. 3.3.1.
${ }^{67} \mathrm{Ibid}$. Art. 3.3.1-3.3.4
${ }^{68} \mathrm{Ibid}$. Art. 3.3.5-3.3.6 
Aeronautical Information Publication (AIP) Volume I General \& Enroute. ${ }^{71}$ In addition, it provides the explanation of Airpot Flight Operation Safety Area that is the area with the horizontal and vertical limits as regulated in the relevant and related rules. ${ }^{72}$ Other additional explanation is that about the term controlled airspace that is an airspace, which is published in the Indonesian Aeronautical Information Publication (AIP) Volume I General \& Enroute. While uncontrolled airspace is defined as the air space outside the Airport Flight Safety, which the function is to serve as Aerodrome Flight Information Service. $^{73}$

The new regulation also provides specific provisions on RPA volume. For example, RPA operations with the weighing no more than $55 \mathrm{lbs}$ and used for non-hobby and leisure purposes shall comply with the provisions of Civil Aviation Safety Regulation (CASR) Part 107. Other provisions stipulate that RPA weighing above $55 \mathrm{lbs}$ for research and development purposes, crew training and market surveys, must register an experimental certificate in accordance with the provisions of CASR Part 21 sub chapter $21.193 .^{74}$

Due to the lack of procedural rules, particularly on the submission of insurance documents and the imposition of legal sanctions, the government issued the Ministerial Regulation No PM $180 / 2015$ to amend this regulation. It provides the provisions concerning the necessity of submitting insurance documents in the application for permits and emphasizing of legal sanctions against negligence and / or breaking the rules of the operation of the
RPAs. With regard to the insurance documents as a requirement for obatining RPA operating permission, it provides as follows: " The applicant for permit should provides information concerning RPA system and supporting documents as follows, ...insurance documents that also covers the damages or losses of third parties caused by the failure of RPA system". 75

Unlike the previous regulation, the new regulation provides more detail about legal sanctions. This will be imposed, among others to unauthorized RPA operations or RPA operations that are not comply with the requirements of the granted permission. In addition, the imposition of the sanctions will take into account the safety interests of airspace users and the protection of buildings and people under the area and airspace used by RPA. ${ }^{76}$ The DGCA has an authority to impose a legal sanction for the RPA that violating the rules at the Airport Flight Safety Operations, Controlled airspace and uncontrolled airspace at the altitudes of more than $500 \mathrm{ft}$ Above Ground Level, while for the RPA that violating the rules at the prohibited and restricted areas, the Indonesian Armed Forces has responsible to impose such a legal sanctions. However, this is not a penal, but rather administrative sanction in the form of, warning, suspension of permits, revocation of permits, and administrative penalties. ${ }^{77}$

\section{Technical Issues}

The preceding discussion reveals that the existing Indoneian RPAs regulation is mostly related to technical issues. It can be seen by assessing three specific issues as

\footnotetext{
75 Permenhub No.PM 47/2016, Art.3.1.1 (k).

${ }^{76}$ Ibid. Art.5.1-5.2.

${ }^{77}$ Ibid.Art.5.3-5.4

${ }^{71}$ Permenhub No.PM 180/2015, Art. 2.2.4

${ }^{72}$ Ibid. Art.2.2.5

${ }^{73}$ Ibid. Art.2.2.3 - 2.2.7
}

${ }^{74}$ Ibid. Art. 3.3.3

68 | Uweh, Ruhaeni - In Search of Remotely Piloted Aircraft Regulations State Practices... 
follows: (i) the process of establishing the regulation, (ii) the form of regulation, and (iii) the substance (the content). The processes of establishing the regulations appear to be intended as short-term response to the wide-ranging RPA operations, which is not followed by an adequate regulation. This is a preliminary response as well as testing the water to see the response of the RPA operators and other stakeholders. One of the serious consequences of that is the regulations are subject to much revision and legal uncertainties are unavoidable facts. The revisions that mostly related to technical explanations and other technical requirements confirmed the ad hoc or temporary nature of the regulations. This can be seen, for example, the technical explanation on the definition of prohibited and restricted areas in Permenhub No PM $180 / 2015$ as these terms are not clearly defined in the previous regulation (Permenhub No.PM 90/2015). Due to the rapid development of RPA technology and its extensive use, it is likely that the existing regulations will continue to follow those developments and hence the revision of the regulation is necessity.

The existing RPA regulations take the form of the Ministerial Regulation, which the content mostly related to technical procedures. This is regarded as the most appropriate legal instrument for two reasons. First, there has been no agreed international regulation governing RPA operation so far. Secondly, RPA technology is still growing, so it will affect the substance of the regulation. However, since the substance of the RPA regulations also covers procedures and mechanism to apply the fundamental principles in air (transportation) law such as state sovereignty over the airspace and safety, Government Regulation (Peraturan Pemerintah) is more appropriate legal form to govern RPA operations. In addition, Government Regulation is an interministerial-rule product, which is substantially more comprehensive as well as its making process, thus it ensures greater legal certainties for the operators and other stakeholders.

As a short-term response, the contents of the Indonesian RPA regulation are limited to technical issues such as licensing, prohibited actions, and segmented aircraft by mass. This uses consent and segmented approach, a variant of RPA regulatory model that is widely used in most Asian and African countries and a number of countries in North and South America. Thus it can be said that the content of Indonesian RPA regulation not only follows, but also represents an ad hoc nature of RPAs regulation accross the world.

\section{The Proposed RPA Regulation Model}

The Chicago Convention, the model of RPA regulations in several countries, and the special interests of Indonesia as an archipelagic state are the three important elements that should be taken into account in the establishment of an appropriate and adequate Indonesian RPA regulation. The recognition of RPA as an aircraft through the amendement Annex 2 of the Convention has brought about specific consequences to the content of the RPA regulations. The Convention provisions are applicable to RPA, especially for civil RPA that uses for international flight. ${ }^{78}$

\footnotetext{
78 Benjamyn Scotts, "Key Provisions in Current
} Aviation Law" in Burt Custers (Ed.), p. 242 
Some key provisions of the Convention which must be considered to be the content of the Indonesian RPA regulation includes; the provision on pilotless, registration, nationality, certificate of airworthiness, noise and emission standards, and investigation of accidents. In addition, there are some provisions other than the Convention, which have the level of urgency to be inserted into the RPA regulation, among others; operators liability, especially liability for the third parties, insurance, and criminal provisions.

RPA regulatory models of most countries accross the World have a number of common elements that can be used as reference for other countries including Indonesia to set up their RPA regulations. They typically use consent and RPA segmented approach by mass, which essentially they apply the Convention provisions, particularly the principle of state sovereignty over airspace to govern RPA operations. In addition, this approach is also a response to the interaction between law and technology, which in fact always put the law lags behind the technology. In this context, Ravich neatly states as follows, "RPA operations demand that aviation authorities around the world re-imagine local, national, and international airspace systems originally designed for manned assets". 79 Therefore, the establishment of RPA regulations that technologically adaptive is the most rational and factual solution.

RPA has widely been used for different purposes including commercial purposes. In this context, to set up RPA regulations the government should take into account the interests of tripartite stakeholders namely, government, manufcaturers (producers), and users. They should not be isolated by their own interests, which are counterproductive

\footnotetext{
${ }^{79}$ Ravich, above n. 26, 317.
}

to RPA operations. For example, the government provides RPA regulatory schemes that are based on nothing more than a public fear of the unknown. States practices reveal that private and public stakeholders reflect the conservatism of the RPA laws in their jurisdiction while vigilantly putting together a safety case that accurately assesses the operational risk while emphasizing the civil benefits of unmanned aviation. ${ }^{80}$

For Indonesia as an archipelagic state with the largest airspace in ASEAN, RPA operations create challenges and opportunities. This large airspace, however, has not properly been managed due to the fact that the numbers of air force personnels who have a constitutional mandate to uphold the state sovereignty over the airspace are limited. This is certainly very susceptible for violation to the Indonesian airspace by foreign aircraft, and this is a challenge that has not been fully resolved. This challenge will certainly be even greater with the operation of RPA in the Indonesian airspace.

Some have observed that RPA operations would facilitate and boost economic activities. The advanced RPA technology would be a sophisticated answer for geographical obstacles of economic development caused by the vast territory of Indonesia that consist of thousands of islands. However, at the same time this opportunity will give rise another challenges, because RPA operations will create new air traffic complications in the Indonesian airspace, which potentially hamper to civil aviation activities. This in turn requires adequate and appropriate regulations to ensure the safety of civil aviation and RPA operations.

The preceding discussion reveals that the content and the form of regulation are the

${ }^{80}$ Ibid, 318.

70 | Uweh, Ruhaeni - In Search of Remotely Piloted Aircraft Regulations State Practices... 
two important aspects that should be taken into consideration in setting up the Indonesian RPA regulation. In terms of content, RPA regulation should refer to the Convention provisions, the States practices, and the interests and the needs of Indonesia as an archipelagic State. With regard to the form of regulation, Government Regulation (Peraturan Pemerintah) is the most appropriate form for two reasons. First, Government Regulations is an interministerial-rule product, which is substantially more comprehensive that ensures greater legal certainties for the stakeholders of RPA operations. Secondly, this form of regulation is more adaptive to changes especially that relates to technical and procedural matters, because unlike an Act (Undang-Undang), this law-making process not subject to political considerations.

\section{CONCLUSIONS AND SUGGESTIONS}

The use of RPAs can be found in virtually all sectors of society, both public and private sectors, even in military domain. RPA operations for different purposes give opportunities as well as challenges, and one the challenges is that the absence of internationally agreed RPA regulation. This eventually makes RPA regulation is decentralized in nature. The Chicago Convention, the model of RPA regulations in several countries, and the special interests of Indonesia as an archipelagic state are the three important elements that should be taken into account in the establishment of an appropriate and adequate Indonesian RPA regulation.

The recognition of RPA as an aircraft through the amendement of Annex 2 of the Convention has brought about specific consequences to the content of the RPA regulations. The Convention provisions are applicable to RPA, especially for civil RPA that uses for international flight. Most countries typically use consent and RPA segmented approach by mass, which essentially they apply the Convention provisions, particularly the principle of state sovereignty over airspace to govern RPA operations. In addition, this approach is also a response to the interaction between law and technology, which in fact always put the law lags behind the technology. For Indonesia as an archipelagic state with the largest airspace in ASEAN, RPA operations create challenges and opportunities. This large airspace, however, has not properly been managed due to the fact that the numbers of air force personnels who have a constitutional mandate to uphold the state sovereignty over the airspace are limited. This is certainly very susceptible for violation to the Indonesian airspace by foreign aircraft, and this is a challenge that has not been fully resolved. This challenge will certainly be even greater with the operation of RPA in the Indonesian airspace.

\section{REFERENCES}

\section{Books}

Abeyratne, Ruwantissa Convention on International Civil Aviation: A Commentary, (Springer, London, 2014).
Chamayou, Gregoire A Theory of The Drone, (The New Press, New York, London, 2015).

Custer, Burt "Drones Here, There and Everywhere: Introduction and Overview" in Burt Custers (Ed.), The 
Future of Drone Use: Opportunities and Threats From Ethical and Legal Perspectives, (Springer).

Giemulla E.M. and Weber, L.International and EU Aviation Law: Selected Issues, (Kluwer Law International, Dordrecht, 2011).

Joint Publication 1-20, Department of Defense Dictionary of Military and Associated Terms, March 23, 1994, as amended through April 15, 1998.

Lebanese Aviation Regulation, General Operating and Flight Rules, (Republic of Lebanon, Ministry of Public Works and Transport, Directorate General of Civil Aviation, 2002)

Zavrsnik, Ales "Situating Drones in Surveillance Societies" in Ales Zavrsnik (Ed), Drones and Unmanned Aerial Systems: Legal and Social Implications for Security and Surveillance, (Springer, London)

\section{Journal Articles}

Marshal, D.M., 'International Regulation of Unmanned Aircraft Operations in Offshore and International Airspace', 87 8, Issues in Aviation Law and Policy.

Dalamakidis, K., Valanis, K.P., and Piegl, L.A., 'Current Status and Future Perspectives for Unmanned Aircraft System Operations in the US', (2008) 52 Journal of Intelligent and Robotic System.

Peterson, Mark Edward, 'The UAV and the current and future regulatory construct for integration into the national airspace system', 713 Journal of Air Law and Commerce.

Bourbonnierre, M., and Haeck, L., 'Military Aircraft and International Law: Chicago Opus3', (2001) 66 Journal of Air Law and Commerce.

Lissitzyn, O.J. , 'The Treatment of Aerial Intruders in Recent Practice and International Law', (1953) 47 The American Journal of International Law.

\section{Internet}

EASA, "European aviation safety agency, concept of operations for drones", 2015.

http://www.cad.gov.hk/english/Unmanned_ Aircraft_Systems.html. Accessed 13 February 2018.

http://www.easa.europa.eu/system/files/dfu/ 204696_EASA_concept_drone_broch ure_web.pdf. Accessed 13 February 2018

Federal Aviation Administration, Section 333 Frequently Asked Questions, https://www.faa. gov/uas/legislative_programs/section_ 333/333_faqs/\#q3. Accessed, 13 February 2018

Fahmy, H eba, "New rules in the works to regulate drone usage in Qatar, Doha News, $26 \quad$ Mar 2015. http://dohanews.co/new-rules-in-theworks-to-regulate-drone-usage-inqatar/. Accessed 13 February 2018

http://web.shgm.gov.tr/en/s/2222procedures-for-certifi- cate-of-specialflight-permit. Accessed 13 February 2018.

Orzea E, "China's UAS regulation: an interesting precedent, November 2014, UAS VISION. http://www.suasnews.com/2014/11/32 433/chinas-uas-regulation-aninteresting- precedent/. Accessed 13 February 2018.

Sharp A, Takahashi M, "Japan to bolster laws after drone lands on Abe's office roof, Bloomberg Business", 22 Apr 2015. http://www.bloomberg.com/news/artic les/2015-04-22/ drone-lands-on-roofof-japanese-prime-minister-s-officein-tokyo.

South African Civil Aviation Authority, Technical Guidance Material for Part 101 Personal Licensing, Advisory Circular, 19 June 2015. http://www.caa.co.za/RPAS\%20

TGM/TGM\%20for\%20Personnel\%20 Licensing\%20Part\%20101\%20(Subpart\%203).pdf. Accessed 13 February 2018.

South Africa Civil Aviation Regulations Committee 2015. Proposed amendment 
of the civil aviation regulations, 2011, proposal for the insertion of part 101 of the civil aviation regulations. www.defenceweb.co.za/_pdf/SA_CA

A_101-

DECEMBER_2014_publication.pdf.

Accessed 13 Februray 2018.

United Arab Emirates, General Civil Aviation Authority, Operation of Unmanned Aerial Systems within the United Arab Emirates, CAR Part VII, Subpart 10, https://www.gcaa.gov.ae/ en/Pages/uas.aspx. Accessed 13 February 2018.

\section{Legislations}

Act No. 74 of 1962 (as amended up to 1991), Namibian Civil Aviation Regulations, 2001.

Amendment No. 6 to the International Standards and Recommended Practices, Aircraft Nationality and Registration Marks (Annex 7 to the Convention on International Civil Aviation), adopted by the Council of ICAO on 7 March 2012.

Amandement No. 43 to International Standards Rules of the Air, Annex 2 The Convention on International Civil Aviation Organization, 7 March 2012.

Amendment No. 43 of Annex 2 of 2012.

Law No.15 of 2002 of the State of Qatar.

Permenhub No.PM 47/2016

Permenhub No. PM 90/2015.

Permenhub No.PM 90/2015

Permenhub No.PM 180/2015

South African Civil Aviation Authority, Technical Guidance Material for RPAS-Part 101, § 6, 30 Sept 2015.

The Chicago Convention 1944. 